\title{
Lactobacillus-based Probiotic Capsule
}

National Cancer Institute

\section{Source}

National Cancer Institute. Lactobacillus-based Probiotic Capsule. NCI Thesaurus. Code C120549.

A capsule containing a strain of the probiotic bacterium Lactobacillus with potential antimicrobial and immunomodulatory activities. As a dietary supplement, Lactobacillus, a naturally-occurring bacteria, may improve digestion and help maintain adequate colonization of the gastrointestinal (Gl) tract by modulating the composition of the normal microflora. Because it produces lactic acid and hydrogen peroxide and other substances during fermentation, this bacterium creates an acidic environment that is unfavorable for pathogens. In addition, during colonization of the Gl tract, this bacterium adheres to human epithelial cells and forms a protective barrier, thereby preventing the attachment of pathogens. Dietary supplementation with this bacterium has been shown to enhance innate and acquired immunity. 